\title{
EFFECT OF ANAESTHESIA AND SURGERY ON BLOOD SUGAR AND CARBOHYDRATE TOLERANCE IN AFRICAN CHILDREN
}

\author{
Dorothy J.O. Ffoulkes-Crabbe and Thomas O. Johnson
}

\section{INTRODUCTION}

Catronimdrate Metabolic responses of children to anaesthesia and surgery have been little studied. ${ }^{1.2}$ In a paper on blood sugar changes in children in response to surgery, Watson ${ }^{1}$ described differences from patterns widely reported for adults.

Among adults, racial differences in the hyperglycaemic response to surgical trauma have been shown by some workers., ${ }^{3,+}$ Recently, however, it was shown that the blood sugar responses of adult Nigerians to anaesthesia and upper abdominal operations did not differ markedly from that shown by Caucasians."

The paucity of data on paediatric responses, the possibility of racial differences in response, and the reported finding of a high prevalence ( 10 per cent and above) of biochemical hypoglycaemia following preoperative starvation ${ }^{1,2,6}$ prompted our study on Nigerian children.

In the study we attempted to ascertain the effect of pre-operative starvation, of amaesthesia, and of anaesthesia and early phase surgery on blood sugar levels, and the effect of anaesthesia and operation on carbohydrate tolerance.

Twenty-eight children under 15 years of age were studied. Apart from the surgical conditions for which they were admitted, the subjects were physically fit and had no evidence of endocrine or metabolic disorders. The routine ward care including feeding schedules for patients were not interfered with.

For the first part of the study, venous samples were taken on the operative day before induction of anaesthesia, 15 minutes after induction and 15 minutes after the start of the operation. To ascertain the effect of anaesthesia and surgery on glucose tolerance, subjects were given an intravenous glucose load of $0.5 \mathrm{gm} / \mathrm{kg}$ body weight over two minutes and blood specimens were collected through an indivelling forearm venous catheter for blood sugar determinations at $5,10,15$, $20,25,30,45,50$ and 60 minutes after the load. The first tolerance test was done some days before operation and was repeated on the day of operation starting 15 minutes after the operation began. Each subject therefore served as his or her own control.

Blood sugar was assayed by the colorimetric method of Asatoor and King ${ }^{7}$ which measures "true sugar."

\section{Anaesthetic Techniques}

Patients were either induced with thiopentone $5 \mathrm{mg} / \mathrm{kg}$ body weight and main-

Dorothy J.O. ffoulkes-Crabbe, M.B., F.F.A.R.C.S., Senior Lecturer in Anaesthesia.

Thomas O. Johnson, M.D., F.R.C.P.(Lond.), Endocrine and Metabolic Unit, Department of Medicine, College of Medicine, University of Lagos, P.M.B. 12003, Lagos, Nigeria. 
TABLE I

Fasting and Blood Sugar Values (mg/100 ml)

\begin{tabular}{cccccccc}
\hline \hline \multirow{2}{*}{$\begin{array}{c}\text { No. of } \\
\text { children } \\
\text { studied }\end{array}$} & $\begin{array}{c}\text { No. of } \\
\text { fasts }\end{array}$ & \multicolumn{2}{c}{ Duration of fast (Hrs) } & & \multicolumn{2}{c}{ Blood sugar } & \multicolumn{2}{c}{$\begin{array}{c}\text { No. of } \\
\text { Range }\end{array}$} & Mean & & Range & Mean & $\begin{array}{c}\text { Nubcts with } \\
\text { B.S. 45 }\end{array}$ \\
\hline 28 & 34 & $8.15-19$ & $14.0 \pm 0.4$ & & $27-85$ & $62 \pm 1.9$ & 2 \\
\hline
\end{tabular}

TABLE II

Fasting Blod Sugar Levels in Relation to Duration of Fasting; AND BODY WEIGHT

\begin{tabular}{|c|c|c|c|c|}
\hline $\begin{array}{l}\text { Number } \\
\text { studied }\end{array}$ & $\begin{array}{c}\text { Age Mean, } \mathrm{SEM} \\
\text { and range }\end{array}$ & $\begin{array}{l}\text { Weights kg. } \\
\text { Nean, SEM } \\
\text { and range }\end{array}$ & $\begin{array}{l}\text { Blood sugar } \\
\text { mg/ } 100 \mathrm{ml} \text {. } \\
\text { Mean, SEM } \\
\text { and range }\end{array}$ & $\begin{array}{l}\text { Fasting period } \\
\text { (in hrs) } \\
\text { Mean SEXI }\end{array}$ \\
\hline 9 & $\begin{array}{c}14.4 \operatorname{mos}(2.9) \\
(2 / 12-24 / 12)\end{array}$ & $\begin{array}{r}9.0(0.98) \\
(3.2-12.7)\end{array}$ & $\begin{array}{c}.74 .2(3.6) \\
(27-62)\end{array}$ & $13.7(0.94)$ \\
\hline $15^{*}$ & $\begin{array}{c}6.7 \text { yrs }(0.5) \\
(4-9 \text { yrs })\end{array}$ & $\begin{array}{c}20.1(0.86) \\
(16.5-2.5)\end{array}$ & $67.6(2.4)$ & $15.4(0.51)$ \\
\hline $10^{*}$ & $\begin{array}{c}14.3 \text { yrs }(0,42) \\
(10-15 \text { yrs })\end{array}$ & $\begin{array}{l}41.1(3.5) \\
26.4-57.6\end{array}$ & $\begin{array}{c}64.8(3.4) \\
(i 2-8 i)\end{array}$ & $12.5(0.76)$ \\
\hline
\end{tabular}

*Subjects tolerance tested had two fast periods.

tained with nitrous oxide, oxygen and curare with controlled ventilation or were induced and maintained with nitrous oxide, oxygen and halothane.

Statistical Evaluation of Results: In comparing mean values by Student's " $\mathrm{t}$ " test, the conventional level of a $p<0.05$ was taken as significant. Unless otherwise stated, the degree of scatter around the means is given as 1 S.E.M.

\section{RESULTS}

The 28 patients, 16 males and 12 females, aged 2 months to 15 years, were operated on for minor ophthalmic, otolaryngological, orthopaedic, plastic and general surgical conditions.

\section{Effect of Preoperative Starvation on Blood Sugar (Table I)}

After a starvation period of 8.5 to 19 hours, the fasting blood sugar varied from 27 to $85 \mathrm{mg} / 100 \mathrm{ml}$ in 34 instances. Sugar values were below $45 \mathrm{mg} / 100 \mathrm{ml}$ ( 42 $\mathrm{mg} / 100 \mathrm{ml}$ and $27 \mathrm{mg} / 100 \mathrm{ml}$ ) in two subjects and none showed clinical signs of hypoglycaemia.

Fasting sugar values in relation to age, body weight and duration of fast are shown in Table II.

Nine children two years of age or less and weighing $3.2 \mathrm{~kg}$ to $12.7 \mathrm{~kg}$ had lower mean blood sugar values than older children of higher mean body weights, after comparable fast periods. The hypoglycaemic values were recorded in two of these nine children. 
TABLE III

Fasting Blood Sugar Values in Tolerance Tested Subjects

\begin{tabular}{|c|c|c|c|c|c|}
\hline & \multirow[b]{2}{*}{$\begin{array}{l}\text { Age } \\
\text { (yrs) }\end{array}$} & \multicolumn{2}{|c|}{ Days before operation } & \multicolumn{2}{|c|}{ Day of operation } \\
\hline & & $\begin{array}{l}\text { Fasting sugar } \\
\mathrm{mg} / 100 \mathrm{ml}\end{array}$ & $\begin{array}{c}\text { Hours } \\
\text { fasting }\end{array}$ & $\begin{array}{l}\text { Fasting sugar } \\
\mathrm{mg} / 100 \mathrm{ml}\end{array}$ & $\begin{array}{l}\text { Hours } \\
\text { fasting }\end{array}$ \\
\hline & $\begin{array}{r}6 \\
4 \\
8 \\
15 \\
9 \\
12\end{array}$ & $\begin{array}{l}72 \\
56 \\
60 \\
54 \\
70 \\
73\end{array}$ & $\begin{array}{l}14 \\
13.5 \\
14.5 \\
10 \\
14.5 \\
10\end{array}$ & $\begin{array}{l}65 \\
86 \\
72 \\
59 \\
72 \\
52\end{array}$ & $\begin{array}{l}15 \\
16 \\
14.75 \\
15.75 \\
17.5 \\
14\end{array}$ \\
\hline $\begin{array}{l}\text { Nean } \\
\pm S E M I\end{array}$ & $9(1,5)$ & $64.2(3.2)$ & $12.75(0.8)$ & $67.7(4.4)$ & $15 . \overline{5}(1.03)$ \\
\hline
\end{tabular}

TABLE IV

Anaesthesia a:d Blood Sugar Values

\begin{tabular}{ccccc}
\hline \hline & & \multicolumn{2}{c}{ Mean $( \pm$ SEM) blood sugar values $(\mathrm{mg} / 100 \mathrm{ml})$} \\
\cline { 3 - 5 } $\begin{array}{c}\text { No. of } \\
\text { subjects }\end{array}$ & $\begin{array}{c}\text { Type of } \\
\text { anaesthesia }\end{array}$ & Pre-induction & $\begin{array}{c}15 \mathrm{~min} \\
\text { Post-induction }\end{array}$ & $\begin{array}{c}30 \mathrm{~min} \\
\text { Post-induction }\end{array}$ \\
\hline 7 & Relaxant & $62.3(2.9)$ & $69.0(3.0)$ & - \\
$20 \dagger$ & Inhalational & $62.3(3.4)$ & $7.2(3.8)$ & - \\
$8^{*}$ & " & $61.6(4.7)$ & $63.4(4.2)$ & $65.3(4.6)$ \\
\hline
\end{tabular}

*Included in $\dagger$.

The fasting sugar values on two occasions in the six subjects who had glucose tolerance tests are shown in Table III. Body weights varied from 12.3 to $47 \mathrm{~kg}$.

There was no significant difference between the first mean fasting sugar value $(64.2 \mathrm{mg} / 100 \mathrm{ml})$ after an average fast of $12 \%$ hours and the mean fasting sugar $(67.4 \mathrm{mg} / 100 \mathrm{ml}$ ) on the day of operation after a significantly longer fast (mean 15.5 hours).

\section{Effect of Anaesthesia on Blood Sugar (Table IV)}

In seven subjects premedicated with atropine and promethazine and anaesthetized with the relaxant technique (thiopentone, d-tubocurane, nitrous oxide and oxygen), the mean pre-induction blood sugar value $(62.2 \mathrm{mg} / 100 \mathrm{ml})$ was significantly lower than the 15 minutes post-induction value $(69.0 \mathrm{mg} / 100 \mathrm{ml})$ $(\mathrm{p}<0.05<0.02)$.

Inhalation anaesthesia with nitrous oxide, oxygen and halothane in unpremedicated subjects produced increases of blood sugar at 15 minutes (20 subjects) and 30 minutes ( 8 subjects); but these were not significantly higher than the mean pre-induction value.

Minor operations under inhalation anaesthesia in seven unpremedicated subjects resulted in a significant mean rise of blood sugar of $20 \mathrm{mg} / 100 \mathrm{ml}$. Similarly, in five subjects under relaxant anaesthesia, following 15 minutes of operation, there was a significant rise of mean blood sugar of $23.2 \mathrm{mg} / 100 \mathrm{ml}$.

The glucose disappearance rate, $\mathrm{K}^{s}$ before and during operation was calculated 
TABLE V

Blood Sugar Values ( $\mathrm{mg} / 100 \mathrm{ml} \pm$ SEM) UNder

ANAESTHESIA AND SURGERY

\begin{tabular}{lcc}
\hline No. of subjects & Post-induction & $\begin{array}{c}15 \text { min after } \\
\text { start of operation }\end{array}$ \\
\hline 7 (inhalational) & $71.4(4.7)$ & $91.4(9.4)^{*}$ \\
\hline (relaxant) & $69.0(2.4)$ & $92.2(3.7)^{*}$ \\
\hline
\end{tabular}

*Significantly higher than post-induction.

TABLE VI

Glucose Disappearance Rate $(n=6)$

\begin{tabular}{lcr}
\hline \hline & Mean K Value & Mean time to zero value \\
\hline Pre-operative & $2.55(0.5)$ & $67.8 \mathrm{~min}(7.0)$ \\
Per-operative & $1.29(0.12)^{*}$ & $123.0 \mathrm{~min}(20.8)^{*}$ \\
\hline
\end{tabular}

*Significantly greater than pre-operative value.

for each of the six subjects aged 4-15 years (mean 9 years) all but one of whom had relaxant anaesthesia.

In Table VI, the mean $\mathrm{K}$ value was significantly higher before the operation (2.55) than during the operation (1.29). Similarly, the mean projected time taken for the blood sugar to return to preload value ${ }^{8}$ was significantly shorter in the preoperative test than during the operation.

\section{Discussion}

In this study, it is clear that age and body weight are important factors in determining the effect of fasting on blood sugar levels in our children. Children in the lower age group who also weighed less had significantly lower sugar values as a result of fasting.

In his report of the incidence of hypoglycaemia in children before operation, Thomas found that 5 of 18 children starved pre-operatively who were less than 47 months old and $15.5 \mathrm{~kg}$ body weight had hypoglycaemia, as opposed to nonc of the 15 children similarly starved who were older than 47 months and who weighed over $15.5 \mathrm{~kg} . "$

None of our children were clinically hypoglycaemic, although two had sugar values in the hypoglycaemic range. The fasting blood sugar level of the average Nigerian adult has been shown to be lower than that in Caucasians" and it is conceivable that the African child can, like the adult, tolerate lower blood sugar without showing signs of hypoglycaemia.

As with non-African adults, ${ }^{10,11.12}$ halothane had no effect on the blood sugar levels in our children. Black and Rea reported little alterntion of blood sugar in Caucasian children during inhalation anaesthesia with methoxyflurane. ${ }^{13}$

Our study, however, revealed a significant effect of relaxant anaesthesia on the blood sugar in Nigerian children. This is contrary to the findings in many studies on adults, ${ }^{3,14}$ including adult Nigerians." The seven children were premedicated 
with promethazine and the mean blood sugar rise following relaxant anaesthetic technique was significant and like that reported by Dundee and Todd in Caucasians who were similarly premedicated and annesthetized. ${ }^{15}$ However, these authors, allowing for the error in their determination of blood sugar (Folin and Wu technique of Hawk, et al. ${ }^{1{ }^{(i}}$ ) suggested that the hyperglycaemic response in their relaxant group was "so small as to be of no clinical significance."

A hyperglycaemic response to anaesthesia and surgery was observed in our paediatric subjects. This response is similar to that reported in adults. ${ }^{5.14}$ Watson's study on 80 children who underwent operation ( 25 with major and 55 with minor surgery) under relaxant technique showed a small but significant mean rise of $8 \mathrm{mg} / 100 \mathrm{ml}$ as a result of surgery. ${ }^{1} \mathrm{He}$ found no relationship between the "stressfullness" of the operation and the rate of rise of blood glucose concentration. Black and Rea had earlier reported that minor surgery in 10 children under methoxyflurane anaesthesia produced no rise of blood sugar. ${ }^{13}$ All our patients had minor operations and, in them, mean blood sugar rise of $20 \mathrm{mg} / 100 \mathrm{ml}$ in the inhalational group and $23.2 \mathrm{mg} / 100 \mathrm{ml}$ in the relaxant group were found following 15 minutes of surgery. This would suggest a more pronounced hyperglycaemic response to surgery in the African children. Glucose disappearance rate during the minor surgical operations on our patients was significantly slower but the high blood sugar values attained during tolerance testing at operation did not affect the postoperative return of consciousness in the patients.

\section{SUMMARY}

The effect of pre-operative starvation, anaesthesia and surgery on blood sugar levels and the handling of carbohydrate load during operation were studied in 28 Nigerian children between 2 months and 15 years of age.

(1) Age and body weight were important factors influencing the relationship between duration of pre-operative fast and the pre-induction blood sugar level in children. Hypoglycaemic values occurred in 7 per cent of the subjects studied although none was clinically hypoglycaemic.

(2) Halothane anaesthesia alone did not affect blood sugar levels but relaxant anaesthesia in this study caused significant rise of blood sugar.

(3) There was a marked hyperglycaemic response to surgery and handling of glucose load during operation was significantly poorer than before operation.

\section{RÉSUMÉ}

Chez 28 enfants d'origine nigérienne âgés de deux mois à 15 ans, on étudié les effets du jeûne pré-opératoire de l'anaesthésie et de la chirurgie sur la glycémie en cours d'opération; on a aussi étudié les effets de ces mêmes facteurs sur l'hyperglycémie provoquée.

(1) Làge et le poids corporel apparaissent comme des facteurs importants daus l'interrelation de la durée du jeûne pré-opératoire et de la glycémie préopératoire. On a observé des niveaux hypoglycémiques chez 7 pour cent des sujets sans cependant aucune manifestation clinique d'hypoglycémie. 
(2) L'anesthésie à l'halothane employé seul n'a pas modifié la glycémie mais l'utilisation de myorésolutifs dans cette étude a provoqué une augmentation sensible de la concentration du sucre sanguin.

(3) La chirurgie en soi a provoqué une réponse hyperglycémique marguée et la tolérance au glucose durant l'opération était nettement réduite par rapport à celle qu'on pouvait observer avant l'opération.

\section{REFERENCES}

1. Watson, B.G. Blood glucose levels in children during surgery. Brit. J. Anaes. 44: 712 (1972).

2. Thomas, M.K.D. Hypoglycaemia in children before operation: its incidence and prevention. Brit. J. Anaesth. 46: 66 (1974).

3. Keatinc, V. Carbohydrate metabolism: the effects of surgery in a tropical population. Anaesthesia 13: 434 (1958).

4. Cullingrond, D.W.J. The blood sugar response to anaesthesia and surgery in Southern Indians. Brit. J. Anaesth. 38: 463 (1966).

5. Magbagbeola, O.A.J. \& Abadevon, B.K. Metabolic response to anaesthesia and upper abdominal surgery in Nigerians: Changes in plasma cortisol, insulin and blood sugar. Brit. J. Anaesth. 46: 942 (1974).

6. Bevan, J.C. \& Burn, C. MarY Acid base and blood glucose levels of paediatric cases at induction of anaesthesia: the effect of preoperative starvation and feeding. Brit. J. Anaesth. 45: 115 (1973).

7. Asatoor, A.M. \& KING, E.J. A simplified colorimetric blood sugar method. Biochem. J., 56: $44(1954)$.

8. Selzer, H.S. Diagnosis of diabetes in "Diabetes mellitus theory and practice." Ed. Ellenberg, M. Rifkin, H. McGraw Hill Book Co. 1970, pp. 469 \& 471.

9. Jornson, T.O. Diabetes mellitus in Lagos (Nigeria): a study of the prevalence of the disorder in an African urban community. M.D. thesis, University of London (1969).

10. Hunter, R.A. Halothane and the blood sugar. Brit. J. Anaesth. 31 : 490 (1959).

11. Keating, V.J., Patrick, S.J., \& Annaniunthodo, H. Halothane and carbohydrate metabolism. Anaesthesia 14: 268 (1959).

12. OYama, T. \& Takazaiva, T. Effect of halothane, anaesthesia and surgery on human growth hormone and insulin levels in plasma. Brit. J. Anaesth. 23: 573 (1971).

13. BLACK, W.C. \& REA, J.L. Effects of methoxyflurane (Penthrane) :maesthesia in children. Brit. J. Anaesth. 36:26 (1964).

14. Clalike, J.S.R. Anaesthesia and carbohydrate metabolism. Brit. J. Anaesth. 45: 237 (1973).

15. DundeE, W.J. \& Topn, M. Clinical significance of the effects of thiopentone and adjuvant drugs on blood sugar and glucose tolerance. Brit. J. Anaesth. 30: 77 (1958).

16. Hawk, P.B., Oser, B.L., \& Sumimerson, W.H. Practical physiological chemistry, 12th ed., p. 520. London: Churchill (1947). 